\title{
The influence of gender on selected risk factors for chronic non-communicable diseases in patients hospitalized in surgical wards: A cross-sectional study
}

\author{
Aleksandra Kołtuniuk ${ }^{A-E}$, Joanna Rosińczuk ${ }^{A, E, F}$ \\ Department of Nervous System Diseases, Faculty of Health Science, Wroclaw Medical University, Poland \\ A - research concept and design; $\mathrm{B}$ - collection and/or assembly of data; $\mathrm{C}$ - data analysis and interpretation; \\ $D$ - writing the article; $E$ - critical revision of the article; $F$ - final approval of the article
}

Address for correspondence

Aleksandra Kołtuniuk

E-mail: aleksandra.koltuniuk@umed.wroc.pl

Funding sources

The project was funded by a grant for young scientists No. PBMN 179 (Wroclaw Medical University, Poland).

Conflict of interest

None declared

Received on July 26, 2016

Reviewed on December 5,2016

Accepted on January 31, 2017

\begin{abstract}
Background. Chronic non-communicable diseases (CNCDs) are the leading cause of mortality in the world. Identification of risk factors and the implementation of preventive measures can effectively reduce the chance of disease and death due to CNCDs.

Objectives. The aim of this study was to analyze selected risk factors of CNCDs in women and men hospitalized in surgical wards.

Material and methods. The study group included 420 patients aged 18-84 years who were hospitalized in surgical wards. All participants were interviewed prior to anthropometric measurements, blood pressure, and fasting blood tests. A statistical analysis of the material was performed with the use of Student's t-test, $X^{2}$ test, Fisher's exact test, Mann-Whitney $U$ test, and analysis of variance (ANOVA).

Results. The analysis of the study material showed abdominal obesity in $63 \%$ of patients, more likely in women ( $p<0.001$ ); increased total cholesterol values in $30 \%$ of patients, more frequently in women $(p=0.025)$; blood pressure values $\geq 140 / 90 \mathrm{~mm} \mathrm{Hg}$ in $28 \%$ of patients, more frequently in men ( $p<0.001)$; alcohol abuse ( $\geq 5$ points in the Michigan Alcoholism Screening Test, MAST) in $12.6 \%$ of patients, more frequently in men $(p<0.001)$.

Conclusions. Both women and men are at risk of developing CNCDs; however, women should pay more attention to psychological counseling and the prevention of obesity and hypercholesterolemia, while men should be educated on how to prevent hypertension and alcohol abuse.
\end{abstract}

Key words: obesity, risk factors, cardiovascular diseases, smoking, diabetes mellitus type 2

DOI

$10.17219 /$ acem/68741

Copyright

Copyright by Author(s)

This is an article distributed under the terms of the

Creative Commons Attribution Non-Commercial License

(http://creativecommons.org/licenses/by-nc-nd/4.0/) 


\section{Introduction}

As a result of globalization, demographic changes and unfavorable changes in lifestyle, i.e., excessive consumption of highly processed foods and sugary drinks and low levels of physical activity that result in an increased number of overweight and obese population, chronic non-communicable diseases (CNCDs) constitute a serious problem for the entire health care sector all over the world. It is estimated that 38 million people died in 2012 due to CNCDs - mainly cardiovascular diseases, diabetes, cancers, and chronic respiratory diseases. In developed countries, they account for $70 \%$ of all deaths. ${ }^{1}$ In Europe, the percentage of deaths caused by CNCDs is even higher $(80 \%)^{2}$

In Poland, the vast majority of the population dies due to chronic non-communicable diseases. In 2012, 46.1 per 10,000 persons died due to cardiovascular diseases, 25.6 per 10,000 persons due to cancer, 5.2 per 10,000 persons due to respiratory diseases, and 1.9 per 10,000 persons due to diabetes. ${ }^{3}$

Therefore, in 2012, the state members of the World Health Assembly decided to implement the program " $25 \times 25$ " which calls for reducing the number of premature deaths due to CNCDs by $25 \% .{ }^{4}$ To accomplish that, the therapeutic team members (doctors, nurses, nutritionists) should take action in the field of primary prevention, i.e., diagnose the incidence and then implement educational activities aimed at reducing or eliminating these factors. This will contribute to a lower number of new cases - and thus deaths - due to chronic non-communicable diseases.

The major modifiable (lifestyle-related) risk factors for CNCDs include: improper diet, smoking, alcohol abuse, low physical activity, elevated levels of blood pressure (BP), total cholesterol (TC), and glucose (GL).

The aim of the study was to analyze the prevalence of selected risk factors (e.g., low level of activity, alcohol abuse, improper diet, obesity, depression, smoking, elevated levels of blood pressure, total cholesterol and glucose) of CNCDs in women and men hospitalized in surgical wards, and identify the target group of patients who should be included in educational program covering the primary prevention of CNCDs during hospitalization.

\section{Material and methods}

This study was a descriptive, cross-sectional survey conducted among 420 patients in the age group 18-84 years, hospitalized in Department of Urology, Department of General Surgery, Department of Orthopedics and Traumatology of the Locomotor System, and Department of Neurosurgery at the University Clinical Hospital in Wrocław, Poland. Persons eligible for the study were patients who, on the examination day, did not have surgery, and their diagnosed condition did not significantly affect their lifestyle in the period of 3 months prior to hospitalization. The exclusion criteria disqualifying prospective participants covered conditions such as cancers, active infectious diseases, and the cases when persons were subjected to surgery within the 3 months prior to the survey. All participants were informed of the purpose and course of the study, and also possibility of withdrawal at any stage. They also signed a written consent to participate in the study.

The research project was approved by the Bioethics Committee (No. KB 566/2013).

The data collected for the study was obtained by the diagnostic survey method implementing tools such as the author's questionnaire and standardized questionnaires, i.e., International Physical Activity Questionnaire (IPAQ), Beck Depression Inventory (BDI), Menu Scoring Method by Starzyńska, Fagerstrom Test for Nicotine Dependence, Michigan Alcoholism Screning Test (MAST), Inventory to Measure Coping Strategies with Stress (Mini-COPE), Chronic Obstructive Pulmonary Disease Questionnaire (COPD Questionnaire), and Systematic Coronary Risk Evaluation (SCORE). ${ }^{5-12}$

Our questionnaire was a survey of own authorship, which included questions about sociodemographic data, i.e., age, sex, marital status, place of residence, education, income per person in the family, socioeconomic status.

Blood pressure (BP) was measured with the use of OMROM M6 Comfort blood pressure monitor (Omron Healthcare, Kyoto, Japan) in accordance with current guidelines recommended by the Polish Society of Hypertension. ${ }^{13}$ The analysis included the mean value of 2 blood pressure recordings.

The BP values over $140 / 90 \mathrm{~mm} \mathrm{Hg}$ on the examination day were regarded as elevated, whereas the group of patients with hypertension (HTN) included persons with documented diagnosis of hypertension or being treated for HTN.

The glucose (GL) and total cholesterol (TC) levels were measured from first morning blood samples taken after a minimum 8-h fast, using CardioChec Brand Analyzers (PTS Panels Co., PTS Diagnostics, USA). The abnormal value of TC was established at the level of $>190 \mathrm{mg} / \mathrm{dL}$ according to the European Guidelines on cardiovascular disease prevention in clinical practice (v. 2012). ${ }^{14}$ Patients with lipid disorders were defined as those with documented disease or taking medications to lower the TC levels in the blood. The established value for abnormal level of glucose was $>100 \mathrm{mg} / \mathrm{dL}$ following the Guidelines on diabetes management in clinical practice (v. 2014). ${ }^{15} \mathrm{~Pa}-$ tients defined as suffering from diabetes (DM) were those with a documented disease or those taking medication to lower their blood glucose levels.

The body mass index (BMI) was calculated as $\mathrm{kg} / \mathrm{m}^{2}$ from the weight and height, measured with the use of medical scales ZMP RADWAG T 6496 (ZMP RADWAG Co., Radom, Poland), in accordance with current guidelines 
announced by the World Health Organization (WHO). ${ }^{16}$ Participants were weighed only in their pyjamas (without shoes). Obesity was defined as a BMI of $30 \mathrm{~kg} / \mathrm{m}^{2}$ or greater.

Waist circumference (WC) in $\mathrm{cm}$ was measured with an insertion tape. Measurements were taken from the midpoint between the iliac crest and the lower ribs measured at the sides. Abdominal obesity was established at waist circumference $\geq 94 \mathrm{~cm}$ in men and $\geq 80 \mathrm{~cm}$ in women. ${ }^{17}$

The Menu Scoring method by Starzyńska was applied to evaluate a diet. A score lower than 12 is indicative of an improper diet.

The International Physical Activity Questionnaire short form was used to evaluate participants' physical activity during the 7 days prior to hospitalization by the frequency (day/week), duration (min/day or h/day), and intensity (sedentary, light, moderate, or vigorous) of physical activity. According to the IPAQ scoring protocol, the data collected was converted to Metabolic Equivalent Task minutes per week (MET-min/wk): total minutes over last 7 days spent on light, moderate, and vigorous activity were multiplied by 3.3, 4.0, and 8.0, respectively, to create MET scores for each activity level. Physical activity levels were also classified into 3 categories: low, moderate and high, according to the scoring system provided by IPAQ. The physical activity of people aged 18-69 years was evaluated according to the guidelines.

The Fagerstrom Test for Nicotine Dependence is a standard instrument in the form of a questionnaire to assess the nicotine addiction. The degree of nicotine addiction is evaluated in 3 categories as low ( $0-4$ points), moderate (5 points), and high (6-10 points).

The Michigan Alcoholism Screening Test is a fast screening tool consisting of 25 questions designed to identify alcoholism in subjects. Obtaining $\geq 5$ points shows the compliance with the examination criteria for alcoholism, 4 points - the examined person is probably an alcoholic, $\leq 3$ points - the examined person is probably not an alcoholic.

The Beck Depression Inventory is used for self-report inventory to assess the level of depression. The result of $0-11$ points indicates a lack of depression, $12-26$ points - mild depression, 27-49 points - moderately severe depression, 50-63 points - very severe depression.

The Chronic Obstructive Pulmonary Disease Questionnaire is a tool which identifies patients who may suffer from COPD, and who have not been diagnosed with other respiratory diseases. It is designed to be used in people over 40 years of age who smoked or smoke cigarettes, or were/ still are exposed to other risk factors for COPD, such as air pollution with dust or chemicals at home or work. The questionnaire consists of 8 questions, and each answer is assigned a number of points. By adding up the points scored in questions $1-8$, the obtained result allows evaluating the risk of COPD. The score of: $\leq 16$ points - suggests the diagnosis of other respiratory diseases, e.g., asthma; $\geq 17$ points - suggests diagnosis of COPD.
The SCORE was computed using all the variables required for its calculation (i.e., sex, age, cigarette addiction, TC level, and systolic BP). Based on the obtained results, the patients were assigned to one of the risk groups: significantly increased $(\geq 10 \%)$, increased (5-9\%), moderate (1-4\%), and low $(0 \%)$. People with diabetes and previously diagnosed cardiovascular disease belong to the group of increased risk.

The Polish version of the inventory Mini COPE was implemented in the study to define strategies for coping with stress (adopted by Zygfryd Juczyński and Nina Ogińska-Bulik). Inventory Mini-COPE consists of 28 statements, which are divided into 14 strategies of coping with stress: active coping, planning, positive reevaluation, acceptance, sense of humor, turn to religion, seeking emotional support, seeking instrumental support, dealing with something different, denial, venting, use of psychoactive substances, cessation, and self-blame.

All the data received from surveys was entered in Microsoft Office Excel 2010 and the statistical analysis of the parameters studied in the paper was performed with the use of STATISTICA software v. 10.0 along with the Student's t-test, $\chi^{2}$ test, Fisher's exact test, the Mann-Whitney U test, and ANOVA. The level of significance was established at $\mathrm{p}<0.05$.

\section{Results}

The study involved 420 patients hospitalized in a general surgery ward (35.3\%), urology (17.9\%), orthopedics traumatology (20.1\%), and neurosurgery (26\%) wards. Among the patients, women accounted for $48.8 \%$ and men for $51.2 \%$ of the studied population. The youngest participant in the study was 18 years old, and the oldest was 84 years old. Table 1 shows some characteristics among the patients.

The analysis of the material showed that significantly more men than women on the examination day were characterized with higher values of $\mathrm{BP}(>140 / 90 \mathrm{~mm} \mathrm{Hg})(\mathrm{p}<0.001)$. However, prior to admission, women were more often diagnosed with HTN (43.4\% vs $40.9 \%)$. In the group of people who on the examination day had BP $\geq 140 / 90 \mathrm{~mm} \mathrm{Hg}, 63 \%$ were suffering from HTN. In contrast, $37 \%$ of the studied population were people with $\mathrm{BP} \geq 140 / 90 \mathrm{~mm} \mathrm{Hg}$, thus requiring further examination for the diagnosis of hypertension.

On the examination day, impaired fasting glucose (IFG) ( $\geq 100 \mathrm{mg} \%$ ) was diagnosed in $18.0 \%$ of women and $20.9 \%$ of men, while increased levels of TC (>190 mg/dL) occurred in $30 \%$ of patients, significantly more often among women than men ( $\mathrm{p}=0.025)$. Prior to admission to the hospital, $11.6 \%$ of patients were diagnosed with DM and 20\% were treated for lipid disorders (Table 2).

Among the patients, 20\% smoke actively, and 21\% were exposed to passive smoking. The vast majority of smokers (84.5\%) declared that they smoke a pack of cigarettes a day or less. Women significantly prevail among patients 
Table 1. Characteristics of the studied group

\begin{tabular}{|c|c|c|c|c|}
\hline \multirow{2}{*}{ Variables } & \multirow{2}{*}{ Total $n=420$} & \multicolumn{2}{|c|}{ Gender } & \multirow{2}{*}{ p-value } \\
\hline & & women $n=205$ & men $n=215$ & \\
\hline Age $(\mathrm{M} \pm \mathrm{SD})$ & $52.4 \pm 16.2$ & $52.4 \pm 16.1$ & $52.3 \pm 16.3$ & $0.929^{a}$ \\
\hline $\begin{array}{l}\text { Place of residence: } \\
\text { rural area } \\
\text { town with } \leq 10,000 \text { inhabitants } \\
\text { city with } 10,000-100,000 \text { inhabitants } \\
\text { city with }>100,000 \text { inhabitants }\end{array}$ & $\begin{array}{l}108(25.7 \%) \\
23(5.5 \%) \\
89(21.2 \%) \\
200(47.6 \%)\end{array}$ & $\begin{array}{l}46(22.4 \%) \\
13(6.3 \%) \\
52(25.4 \%) \\
94(45.9 \%)\end{array}$ & $\begin{array}{c}62(28.8 \%) \\
10(4.6 \%) \\
37(17.2 \%) \\
106(49.3 \%)\end{array}$ & $0.123^{b}$ \\
\hline $\begin{array}{l}\text { Maritial status: } \\
\text { single } \\
\text { married } \\
\text { widow/widower }\end{array}$ & $\begin{array}{c}106(25.3 \%) \\
271(64.7 \%) \\
42(10 \%)\end{array}$ & $\begin{array}{c}47(22.9 \%) \\
127(62.0 \%) \\
31(15.1 \%)\end{array}$ & $\begin{array}{c}59(27.6 \%) \\
144(67.3 \%) \\
11(5.1 \%)\end{array}$ & $0.003^{\# b}$ \\
\hline $\begin{array}{l}\text { Education: } \\
\text { basic } \\
\text { basic vocational } \\
\text { secondary vocational } \\
\text { high school } \\
\text { post-secondary } \\
\text { bachelor's degree } \\
\text { master's degree }\end{array}$ & $\begin{array}{c}35(8.4 \%) \\
76(18.1 \%) \\
111(26.5 \%) \\
74(17.7 \%) \\
12(2.9 \%) \\
9(2.2 \%) \\
102(24.3 \%)\end{array}$ & $\begin{array}{l}25(12.3 \%) \\
34(16.7 \%) \\
39(19.1 \%) \\
43(21.1 \%) \\
8(3.9 \%) \\
6(2.9 \%) \\
49(24 \%)\end{array}$ & $\begin{array}{c}10(4.6 \%) \\
42(19.5 \%) \\
72(33.5 \%) \\
31(14.4 \%) \\
4(1.9 \%) \\
3(1.4 \%) \\
53(24.7 \%)\end{array}$ & $0.002^{\# b}$ \\
\hline $\begin{array}{l}\text { Professional activity: } \\
\text { student (up to } 26 \text { years) } \\
\text { labourer } \\
\text { white-collar worker } \\
\text { disability retiree } \\
\text { pensioner } \\
\text { unemployed }\end{array}$ & $\begin{array}{l}22(5.2 \%) \\
44(10.5 \%) \\
122(29.1 \%) \\
48(11.4 \%) \\
141(33.6 \%) \\
43(10.2 \%)\end{array}$ & $\begin{array}{l}12(5.9 \%) \\
15(7.3 \%) \\
60(29.3 \%) \\
17(8.3 \%) \\
80(39 \%) \\
21(10.2 \%)\end{array}$ & $\begin{array}{l}10(4.7 \%) \\
29(13.5 \%) \\
62(28.8 \%) \\
31(14.4 \%) \\
61(28.4 \%) \\
22(10.2 \%)\end{array}$ & $0.049^{\# b}$ \\
\hline $\begin{array}{l}\text { Socioeconomic status*: } \\
\text { high } \\
\text { medium } \\
\text { low }\end{array}$ & $\begin{array}{c}n=325 \\
82(25.5 \%) \\
184(56.6 \%) \\
59(18.2 \%)\end{array}$ & $\begin{array}{c}n=162 \\
43(26.5 \%) \\
89(54.9 \%) \\
30(18.5 \%)\end{array}$ & $\begin{array}{c}n=163 \\
39(23.9 \%) \\
95(58.3 \%) \\
29(17.8 \%)\end{array}$ & $0.817^{b}$ \\
\hline
\end{tabular}

$M$ - mean; SD - standard deviation; ${ }^{a}$ - Student's t-distribution test; ${ }^{b}-x^{2}$ test; ${ }^{\#}$ significant differences $(p<0.05)$; ${ }^{*}$ respondents subjectively assessed their economic status.

Table 2. Prevalence of individual CVD risk factors in patients

\begin{tabular}{|c|c|c|c|}
\hline \multirow[b]{2}{*}{ Variable } & \multicolumn{2}{|c|}{ Gender } & \multirow[b]{2}{*}{$p$-value } \\
\hline & $\begin{array}{l}\text { women } \\
n=205\end{array}$ & $\begin{array}{c}\text { men } \\
n=215\end{array}$ & \\
\hline $\mathrm{BP}>140 / 90 \mathrm{~mm} \mathrm{Hg}^{*}$ & $20 \%$ & $36.6 \%$ & $<0.001$ \\
\hline Hypertension & $43.4 \%$ & $40.9 \%$ & NS \\
\hline $\mathrm{GL}>100 \mathrm{mg} / \mathrm{dL}^{*}$ & $18 \%$ & $20.9 \%$ & NS \\
\hline Diabetes & $11.7 \%$ & $11.6 \%$ & NS \\
\hline $\mathrm{TC}>190 \mathrm{mg} / \mathrm{dL}^{*}$ & $35.1 \%$ & $25.1 \%$ & 0.033 \\
\hline Hypercholesterolemia & $22.4 \%$ & $19.1 \%$ & NS \\
\hline Excessive weight & $58.5 \%$ & $65.1 \%$ & NS \\
\hline Overweight & $35.1 \%$ & $40.9 \%$ & NS \\
\hline Obesity & $23.4 \%$ & $24.2 \%$ & NS \\
\hline Abdominal obesity & $74.6 \%$ & $62.9 \%$ & $<0.001$ \\
\hline Current smoking & $18.5 \%$ & $21.4 \%$ & NS \\
\hline Abuse alcohol & $2.2 \%$ & 19.2 & $<0.001$ \\
\hline Improper diet & $93.7 \%$ & 95.3 & NS \\
\hline Low level of activity & $22.9 \%$ & $24.2 \%$ & NS \\
\hline Symptoms of depression & $13.2 \%$ & $5.2 \%$ & 0.016 \\
\hline
\end{tabular}

* on the examination day; NS - not statistically significant; $\mathrm{BP}$ - blood pressure; GL - glucose; TC - total cholesterol. who are occasional smokers $(\mathrm{p}<0.001)$, whereas men prevail among patients smoking 2 packs a day or more $(\mathrm{p}<0.001)$. The mean number of points obtained by smokers in the Fagerstrom test evaluating the degree of dependence on nicotine was $4.09 \pm 2.41$. A significantly higher number of points was obtained by men than women $(p=0.002)$. In $1 / 3$ of all smokers (including $2 / 3$ of smokers over 40 years) appears the risk of developing COPD. This group represents $7.3 \%$ of the study population. Gender does not affect the risk of developing COPD. It was also revealed that $7 \%$ of patients think that they are exposed to inhalation of air contaminated by exhaust fumes and gases (e.g., $\mathrm{CO}_{2}, \mathrm{SO}_{2}$ ) in the workplace - men more often than women $(\mathrm{p}<0.01)$.

The analysis of the study material concerning the risk of death from cardiovascular diseases (CVD) showed that:

- $1 / 4$ of patients belongs to the low-risk group, more women than men $(\mathrm{p}<0.001)$;

- over $1 / 3$ of patients belong to a group of moderate risk, more men than women $(\mathrm{p}<0.001)$;

- every $10^{\text {th }}$ patient belongs to a high-risk group;

- over $1 / 3$ of patients belong to a group of significantly increased risk, more men than women $(\mathrm{p}<0.001)$. 
It was also shown that the average risk of death according to the SCORE scale was $6.3 \%$ for men; however, it was much lower for women (2.6\%).

The analysis of the study material showed no statistically significant difference in the number of people with abnormal body weight in terms of gender. However, women (74.6\%) significantly more often than men (62.9\%) are characterized by abdominal obesity (Table 2 ).

Evaluation of the diet showed that $64.4 \%$ of patients eat only 3 meals a day. Men consume fewer meals per day than women $(p<0.01)$ and their menu also less often includes milk, cheese, fruit and vegetables $(\mathrm{p}<0.05)$. In the studied group of patients, almost half of them declared consuming fish once a week, and $30 \%$ do not eat fish at all (or they do very rarely). In contrast, $1 / 3$ of patients consume sweets every day or a few times a week, and about $30 \%$ claim that they consume more than 5-6g (a teaspoon) of table salt daily (more men than women; $\mathrm{p}=0.007$ ). The average total number of points obtained by patients was $8.92 \pm 4.53$. This means that the diet of patients is improper. Only slightly more than $5 \%$ of patients reached a score ranging from 12 to 27 points (their menu is just sufficient or satisfactory). Women more often obtained a greater mean number of points in the menu survey (9.4) than men (8.5) ( $\mathrm{p}=0.035)$.

In the study group, $43.1 \%$ of patients do not drink alcohol, and women are more likely to be abstinent than men $(\mathrm{p}<0.001)$. In contrast, men are overrepresented both among social drinkers $(\mathrm{p}<0.01)$ and people who drink regularly $1(\mathrm{p}=0.024)$ or $2(\mathrm{p}=0.048)$ drinks a day. The analysis of the data obtained through the MAST questionnaire showed that:

- $12.6 \%$ of patients met the criteria for alcoholism, more men than women $(\mathrm{p}<0.001)$;

- $7.1 \%$ of alcohol drinkers probably have a problem with alcohol abuse, more men than women $(p=0.001)$;

- women are characterized by better culture of drinking alcohol (obtained lower mean number of points -0.3 vs $3.2 ; \mathrm{p}<0.001)$ than men.

The analysis of the study material obtained through IPAQ survey showed that women gained an average of $3815 \pm 5069 \mathrm{MET}$ (min/week), and men $3901 \pm 4574 \mathrm{MET}$ (min/week) ( $\mathrm{p}>0.05)$. The analysis also showed that high physical activity is characteristic for every $3^{\text {rd }}$ patient; $44 \%$ declared moderate activity, and the remaining $23.5 \%$ of patients assess their activity as light. There was no significant difference in activity levels in terms of gender.

At the time of examination, $91 \%$ of patients had no symptoms suggestive of depression, whereas symptoms of mild depression were observed in $8.3 \%$ of the patients, more frequently in women $(\mathrm{p}=0.005)$. The analysis of BDI showed that women significantly more often received more points than men (4.0 vs $2.7 ; \mathrm{p}=0.013$ ).

Patients, most often in situations of severe stress, apply the method of finding emotional support $(2.41 \pm 0.66$ points) and actively coping with stress ( $2.38 \pm 0.59$ points). In contrast, hardly ever, in difficult moments do they turn to psychoactive substances $(0.13 \pm 0.41$ points $)$ or apply the method of denial $(0.23 \pm 0.47$ points). When going through rough patches, women more often than men try to occupy themselves with something else to not think about the problem $(\mathrm{p}<0.001)$; their attention is directed towards religion $(\mathrm{p}<0.001)$, discharging emotions $(\mathrm{p}<0.001)$ or ceasing all activities $(\mathrm{p}=0030)$. In contrast, men are more likely to actively cope with stress $(\mathrm{p}=0.014)$ or plan on how to solve the problem $(\mathrm{p}=0.016)$.

Among the immediate family members of patients (parents, siblings, grandparents), there have been reported a number of chronic non-communicable diseases, i.e.,:

- hypertension was diagnosed in immediate family members of $50 \%$ of patients;

- immediate family members of every $3^{\text {rd }}$ patient suffer from coronary heart disease or had a myocardial infarction;

- immediate family members in $1 / 5$ of patients had a stroke;

- $29.3 \%$ of patients' family members suffer from diabetes.

Nearly $2 / 3$ of the patients have a positive family history of cardiovascular diseases, i.e., meaning that the immediate family members were diagnosed with hypertension, ischemic heart disease, heart attack or stroke, while almost $1 / 3$ of patients had a family history of developing diabetes. In families of female patients, immediate members of family were significantly more frequently diagnosed with cardiovascular diseases $(\mathrm{p}<0.001)$ and diabetes $(\mathrm{p}=0.033)$.

The analysis of the study material revealed the following correlations at the significance level of $\mathrm{p}<0.005$ :

- weak positive correlation between age and SBP values $(\mathrm{r}=+0.258)$, values of DBP $(\mathrm{r}=+0.121)$, glucose levels $(\mathrm{r}=+0.304)$, total cholesterol levels $(\mathrm{r}=+0.161)$, and Beck Depression Inventory $(r=+0.267)$;

- weak negative correlation between age and the level of physical activity $(\mathrm{r}=0.168)$;

- weak positive correlation between BMI and SBP values $(r=+0.368)$, values of DBP $(r=+0.322)$, glucose levels $(r=+0.274)$, serum TC $(r=+0.143)$, and the result of the SCORE scale $(\mathrm{r}=0301)$;

- weak positive correlation between waist circumference and the values of DBP $(r=+0.287)$, glucose level $(\mathrm{r}=+0.319)$, TC level $(\mathrm{r}=+0.105)$, the Beck Depression Inventory result $(\mathrm{r}=+0.106)$, and the MAST test result $(\mathrm{r}=+0.252)$;

- moderate positive correlation between waist circumference and SBP values $(r=+0.403)$;

- high positive correlation between waist circumference and the SCORE scale result $(\mathrm{r}=+0.500)$.

The studies showed that, with age, the value of SBP increases and the growth rate is approx. $0.26 \mathrm{~mm} \mathrm{Hg} /$ year. It was also shown that the relationship between the age factor and SBP is stronger in women than in men. The value of SBP also increases with increasing values of BMI and waist circumference. This dependence is stronger in women than in men. 


\section{Discussion}

Due to the global spread and a high share in overall mortality, CNCDs pose a serious problem in both medical and economic terms for the entire health sector. By identifying risk factors for these diseases, we can effectively reduce the number of new cases and premature deaths caused by them, as well as decrease the costs associated with the treatment and loss of full capacity for active independent life. In the present study, the attempt was made to identify selected risk factors for CNCDs among patients hospitalized in surgical wards with a special focus on gender as a variable affecting prevalence of the risk factors.

Hypertension is one of the major risk factors for CVD incidence such as stroke, and, as a consequence, has a significant impact on the prevalence and mortality. ${ }^{18-20}$ Studies carried out in China and USA showed that HNT is a predictor for the occurrence of higher TC values. ${ }^{21,22}$ Own study confirmed that HTN is slightly more frequently diagnosed in women than in men; ${ }^{23}$ however, many authors indicated that HTN is more common in men. ${ }^{24-28}$ In Bosnia and Herzegovina and Brazil, approx. $40 \%$ of men are treated for HTN, which is the same result as the one obtained in own study. ${ }^{27,29}$ The research carried out in Lithuania showed, however, that over $70 \%$ of local men suffer from HTN. ${ }^{25}$

The increased level of $\mathrm{TC}$ is one of the most important risk factors contributing to the development and death from CVD. ${ }^{30,31}$ The study carried out in the USA showed, however, that hypercholesterolemia is a predictor for hypertension and diabetes. ${ }^{22}$ In our study, increased levels of TC ( $>190 \mathrm{mg} / \mathrm{dL}$ ) occurred on examination day more frequently in women (57.1\%) than in men (42.9\%), which confirmed the findings of other authors. ${ }^{21,25}$ In Bahrain, Malaysia and Norway increased levels of TC were, on the other hand, more frequently observed in men. ${ }^{23,28,32}$

Studies in many countries have shown that patients with increased glucose levels or diabetes more often suffer from CVD, stroke and obesity. ${ }^{18-20,33-35}$ The study by Sun et al. showed that the presence of higher TC values correlates with diabetes. ${ }^{21}$ In the USA, approx. $25 \%$ of women suffer from DM. ${ }^{22}$ In the present study, the percentage was much lower, and gender did not affect significantly the number of people with diabetes, as was confirmed by the results of other authors. ${ }^{24,25}$ In Malaysia and Lebanon, women were significantly more likely to develop DM; ${ }^{23,36}$ however, other studies showed that men often had a significantly higher values of GL. ${ }^{21,37}$ On examination day, the IFG ( $\geq 100 \mathrm{mg} \%$ ) were diagnosed in $18.0 \%$ of women and $20.9 \%$ of men. A similar proportion of men with IFG was reported by other authors. ${ }^{29,32,38}$

Smokers are predisposed to developing HTN, stroke and COPD. ${ }^{18,19,26,39,40}$ Smokers with diabetes or the ones having increased blood glucose levels are exposed to a higher risk of complications and premature death. ${ }^{41}$ In 2005, the smoking addiction affected $42 \%$ of Polish males and $25 \%$ of Polish females. ${ }^{42}$ Although, in recent years, there has been a decrease in the number of active smokers, still about 15-20\% of the population in developed countries are active smokers. ${ }^{28,29,32,43-47}$ This was confirmed by the results of own study.

Most likely, the reduction in the percentage of smokers in the European Union was influenced by the introduction of laws prohibiting smoking in public places. In our study, there was no statistically significant difference between women and men in terms of the number of smokers. In contrast, mainly in developing countries, men are more often active smokers. ${ }^{23,25,27}$

In the present study, $11.2 \%$ of the respondents were characterized by an increased risk of death due to CVD within the next 10 years (from 5-9\%) and $36.6 \%$ had a significantly increased risk (>10\%). Similar results were also obtained in Finland, where $27 \%$ of women and $63 \%$ of men were assigned to a group of high 10-year risk of death from cardiovascular disease $(>5 \%) .{ }^{48}$ In Romania, the percentage was slightly lower and amounted to $25 \%{ }^{49}$ In contrast, the study in France showed that only 1\% of respondents was characterized by a $5 \%$ or greater 10 -year risk of CVD death. ${ }^{44}$ This is probably related to the effective prevention of risk factors for CVD (decrease in the number of smokers and those suffering from HTN). Therefore, over 6 years (2007-2012), a decrease in the 10-year risk of CVD death in both men and women was observed. The test results of MONICA and SEPHAR survey showed that among men the average risk of death, according to the SCORE scale, is around 5\%, whereas for women it was much lower (around 2\%). ${ }^{49,50}$ In the present study, similar results were obtained. However, the results from the HAPIEE study (conducted in the Czech Republic, Poland and Russia) showed that the mean value representing the risk of death for men was approx. 7.5\% (the lowest rate was recorded in Poland $-7.37 \%$, the highest in Russia - 9.07\%), while the risk of death from CVD among surveyed women was 3 times lower. ${ }^{50}$

Meta-analyzes of several studies demonstrated a significant influence of overweight and obesity on the development of many chronic diseases. People with excess body weight are more likely to develop DM, CVD (including HTN and stroke), dyslipidemias, chronic respiratory disease, i.e., COPD, as well as mood disorders, i.e., depression. ${ }^{20-22,26,29,38,51-54}$ In the present study, up to $58.5 \%$ of women and $66 \%$ of men had excessive body weight (BMI >25). Among government officials in Bahrain and professional drivers in Brazil, this percentage was even higher, which may be associated with sedentary type of work. ${ }^{29,32}$ The inhabitants of developing countries were also characterized by a higher percentage of excessive body weight both in women and in men. ${ }^{24,25}$ In contrast, residents of low-income countries were characterized by a lower percentage of overweight and obese population than our study showed. ${ }^{26,55}$ In the present study, $23.4 \%$ of women and $24.2 \%$ of men had varying degrees of obesity (BMI >30). However, in many countries, the proportion of obese women was much higher than in our study. ${ }^{22,23,25}$ 
It was also shown that $\mathrm{WC}>80 \mathrm{~cm}$ for women and $>94 \mathrm{~cm}$ for men is a strong predictor for the development of HTN, DM and dyslipidemia, and strongly correlated with increased mortality due to CVD and chronic respiratory diseases in particular..$^{33,56-60}$ In the present study, $74.6 \%$ of women and $62.9 \%$ of men were characterized by abdominal obesity. Similar results were also obtained by other authors. ${ }^{32}$ In Brazil, the percentage of men with abdominal obesity was a bit smaller, but it is due to different criteria for obesity (WC $>102 \mathrm{~cm}$ ). ${ }^{29}$ However, in Nigeria, only $9 \%$ of men are characterized by abdominal obesity. ${ }^{55}$ This is most likely related to the different measurement criteria (WC >102 cm) and the large energy expenditure during agricultural work. In contrast, a large percentage of Nigerian women (over 50\%), despite the different criteria (WC $>88 \mathrm{~cm}$ ) were characterized by abdominal obesity, which is associated with sedentary work (mainly trade). ${ }^{55}$

Poor eating habits play an important role in the development of CVD and DM. ${ }^{14,18,61,62}$ The WOBASZ study showed that Poles consume too little cereal, milk and fish. ${ }^{63}$ This is confirmed by results of our study. Only $31.9 \%$ of women and $17.7 \%$ of men consumed $4-5$ meals a day, while only $11 \%$ of patients consumed 5 servings of vegetables or fruit each day. In the USA, a similar percentage of the population eat fruit and vegetables in the recommended amounts, while in Bahrain or Nepal an even smaller percentage of those surveyed eat 5 servings of vegetables or fruit, which is definitely associated with lower socio-economic status of Nepalese. ${ }^{26,32,46}$ Studies demonstrated that every additional gram of salt in the diet increased the chance of developing HTN by $14 \% .{ }^{26}$ In the present study, every $3{ }^{\text {rd }}$ patient overuses salt when preparing food, while in the USA only $0.6 \%$ of Americans consume less than recommended $5-6$ g of salt per day. ${ }^{46}$

The authors of numerous studies have shown that alcohol increases the risk of HTN, stroke, triglyceridemia, and DM. ${ }^{26,64-66}$ The EZOP Poland study showed that approx. $10.9 \%$ of respondents (18.6\% of men and $3.3 \%$ of women) abuse alcohol; ${ }^{67}$ these results were confirmed in present study. In Germany, approx. $7 \%$ of the population consumed "dangerous" amounts of alcohol - men more frequently than women. ${ }^{43}$ However, in Nepal, people with low socioeconomic status (approx. 25\% of respondents) consumed 5 or more doses of alcohol each day. ${ }^{26}$

Low level of physical activity (PA) is strongly correlated with the incidence of CVD, hemorrhagic stroke, and diabetes. ${ }^{19,34,61,68}$ Smokers characterized by low levels of PA are more likely to develop COPD. ${ }^{39}$ In contrast, people leading a sedentary lifestyle often exhibit symptoms of depression. ${ }^{69}$ The NATPOL 2011 showed that the number of physically inactive Poles was $28.2 \%$ of the population. ${ }^{70}$ The IPAQ results obtained in the survey conducted among residents of Warszawa showed that $32 \%$ of them were characterized by low levels of PA, while our study results showed that $23.5 \%$ of respondents were characterized by low levels of PA (by IPAQ). ${ }^{71}$ The studies conducted in Mexico and Norway showed that men are more physically active than women. ${ }^{24,28}$ In Lithuania, the opposite tendency was observed. ${ }^{25}$ Our findings did not confirm the gender dependence.

Many studies have reported the influence of depression on the risk of developing CVD, stroke and obesity ${ }^{18,72-76}$ The EZOP Poland study showed that women more often show symptoms of depression. ${ }^{67}$ The present study confirmed this dependence. The study conducted by Cooper et al. among African Americans showed that the greater the abdominal obesity, the more intensive depressive symptoms are. ${ }^{76}$ Our study confirmed a positive correlation between WC and the BDI.

Our study findings showed that actively coping and seeking emotional support are the most commonly used strategies in tackling stress among surgical patients. Moreover, the patients who have been subjected to neurological rehabilitation because of a history of stroke, most often cope with stress with the abovementioned strategies. ${ }^{77}$ Our study showed that a higher intensity of depressive symptoms in the study group resulted in more frequent use of dysfunctional strategies in stressful situations, i.e., self-blame, which was confirmed by Klein et al. ${ }^{78}$ This is probably the consequence of the fact that people who are not able to cope with stress actively experience the feeling of hopelessness resulting in bad mood.

\section{Conclusions}

Gender does not differentiate patients in terms of the number of diagnosed risk factors.

Women were significantly more frequently characterized by increased values of TC and diagnosed with depression and abdominal obesity, while men more often were characterized by the values of $\mathrm{BP} \geq 140 / 90 \mathrm{~mm} \mathrm{Hg}$ and alcohol abuse.

Men's diet is less balanced and varied when compared to women's diet.

Abdominal obesity significantly increases the risk of HTN, and this dependence is stronger in women than in men.

In women, the average risk of death from CVD according to the SCORE scale is 2.5 times lower than in men.

Members of a therapeutic team should implement measures to identify modifiable risk factors for CNCDs in patients hospitalized in surgical wards, especially among men, and apply proper educational activities for prevention purposes in the abovementioned groups.

\section{Strengths and limitations}

This paper is a pioneer study carried out among patients who were treated in hospital for surgical reasons and additionally agreed to participate in the study aiming to determine the prevalence of CNCDs in the Polish population. The results confirmed the need for developing preventive 
measures against increasing prevalence of CNCD among Polish population. The interdisciplinary team has a chance to diagnose the first symptoms of CNCDs or their risk factors often only during hospitalization for other reasons (i.e., surgical reason) when the direct contact with a patient allows for thorough examination. Next interdisciplinary team should select a group of patients who will be subjected to additional educational activities. These activities could be carried out by nurses as one of their responsibilities is patient education.

However, there were a few limitations to the study. The first one concerned the questions which focused on physical activity within the last 7 days prior to hospitalization, and patients usually change their routine before surgery. The second limitation refers to a higher BP level resulting probably from the stress connected with surgery. The last limitation is connected with self-report instruments used in this study which provide subjective assessment of the current reality.

\section{References}

1. Globalstatus reporton noncommunicable diseases. Geneva:WHO;2014.

2. Leading causes of death in Europe: Fact sheet 2012. Copenhagen: WHO Regional Office for Europe; 2012. http://www.who.int/mediacentre/factsheets/fs310_2008.pdf. Accessed July 27, 2015.

3. Rocznik demograficzny 2014. Warszawa: GUS; 2014.

4. Sixty-fifth World Health Assembly, second report of Committee A. A65/54. Genewa: WHO; 2012.

5. Biernat E, Stupnicki R, Gajewski A. Międzynarodowy Kwestionariusz Aktywności Fizycznej (IPAQ) (Polish version). WFIZ. 2007;51(1):47-54.

6. Beck AT, Ward CH, Mendelson M, Mock J, Erbaugh J. An inventory for measuring depression. Arch Gen Psychiatry. 1961;4:561-571.

7. Ciborowska H, Rudnicka A. Żywienie zdrowego i chorego człowieka. Warszawa: PZWL; 2014.

8. Heatherton TF, Kozlowski LT, Frecker RC, Fagerström KO. The Fagerström Test for Nicotine Dependence: A revision of the Fagerström Tolerance Questionnaire. Br J Addict. 1991;86:1119-1127.

9. Selzer ML. The Michigan alcoholism screening test: The quest for a new diagnostic instrument. Am J Psychiatry. 1971;127:1653-1658.

10. Juczyński Z, Ogińska-Bulik. Narzędzia pomiaru stresu i radzenia sobie ze stresem. Warszawa: Pracownia Testów Psychologicznych; 2009.

11. Levy ML, Fletcher M, Price DB, Hausend T, Halbert RJ, Yawn BP. International Primary Care Respiratory Group (IPCRG) Guidelines: Diagnosis of respiratory diseases in primary care. Prim Care Respir J. 2006;15:20-34. doi:10.1016/j.pcrj.2005.10.004

12. Conroy RM, Pyörälä K, Fitzgerald AP, et al. Estimation of ten-year risk of fatal cardiovascular disease in Europe: The SCORE project. Eur Heart J. 2003;24:987-1003.

13. Widecka K, Grodzicki T, Narkiewicz K, Tykarska A, Dziwura J. Zasady postępowania w nadciśnieniu tętniczym - 2011 rok. Wytyczne Polskiego Towarzystwa Nadciśnienia Tętniczego. Nadciśn Tętn. 2011;11:55-82.

14. Perk J, De Backer G, Gohlke H, et al. European Guidelines on cardiovascular disease prevention in clinical practice (version 2012). The Fifth Joint Task Force of the European Society of Cardiology and Other Societies on Cardiovascular Disease Prevention in Clinical Practice (constituted by representatives of nine societies and by invited experts). Eur Heart J. 2012;33:1635-1701. doi:10.1093/eurheartj/ehs092

15. Zalecenia kliniczne dotyczące postępowania u chorych na cukrzycę 2014. Stanowisko Polskiego Towarzystwa Diabetologicznego. Diabetol Klin. 2014;3(Suppl A):1-72.

16. Section 3: Guide to Physical Measurements (Step 2). Available from: www. who.int/entity/chp/steps/Part3_Section3.pdf. Accessed July 27, 2015

17. Alberti K, Zimmet PZ, Shaw J, Grundy SM. The IDF consensus worldwide definition of metabolic syndrome. Brussels, Belgium, International Diabetes Federation; 2006 Available from: https://www.idf. org/e-library/consensus-statements/60-idfconsensus-worldwidedefinitionof-the-metabolic-syndrome. Accessed July 25, 2015.
18. O'Donnell MJ, Xavier D, Liu L, et al. Risk factors for ischaemic and intracerebral haemorrhagic stroke in 22 countries (the INTERSTROKE study): A case-control study. Lancet. 2010;376:112-123. doi:10.1016/ S0140-6736(10)60834-3

19. Blomstrand A, Blomstrand C, Ariai N, Bengtsson C, Björkelund C. Stroke incidence and association with risk factors in women: A 32-year follow-up of the Prospective Population Study of Women in Gothenburg. BMJ Open. 2014;4:e005173. doi:10.1136/bmjopen-2014-005173

20. Islami F, Mańczuk M, Vedanthan R, et al. A cross-sectional study of cardiovascular disease and associated factors. Ann Agric Environ Med. 2011;18:255-259.

21. Sun G-Z, Li Z, Guo L, Zhou Y, Yang H-M, Sun Y-X. High prevalence of dyslipidemia and associated risk factors among rural Chinese adults. Lipids Health Dis. 2014;13:189. doi:10.1186/1476-511X-13-189

22. Nahhas GJ, Daguise V, Ortaglia A, Merchant AT. Determinants of major cardiovascular risk factors among participants of the South Carolina WISEWOMAN program, 2009-2012. Prev Chronic Dis. 2014;11:E153. doi:10.5888/pcd11.140044

23. Amiri M, Majid H, Hairi F, Thangiah N, Bulgiba A, Su T. Prevalence and determinants of cardiovascular disease risk factors among the residents of urban community housing projects in Malaysia. BMCPublic Health. 2014;14:S3. doi:10.1186/1471-2458-14-S3-S3

24. Salas R, Bibiloni M del M, Ramos E, et al. Metabolic syndrome prevalence among northern Mexican adult population. PLoS One. 2014;9:e105581. doi:10.1371/journal.pone.0105581

25. Luksiene D, Tamosiunas A, Baceviciene M, et al. Trends in prevalence of dyslipidaemias and the risk of mortality in Lithuanian urban population aged 45-64 in relation to the presence of the dyslipidaemias and the other cardiovascular risk factors. PLoS One. 2014;9:e100158. doi:10.1371/journal.pone.0100158

26. Dhungana RR, Devkota S, Khanal MK, et al. Prevalence of cardiovascular health risk behaviors in a remote rural community of Sindhuli district, Nepal. BMC Cardiovasc Disord. 2014;14:92. doi:10.1186/1471-2261-14-92

27. Pilav A, Brankovic S, Doder V. Ten year trends in cardiovascular risk factors in the Federation of Bosnia and Herzegovina. Med Arch. 2014;68:394-398. doi:10.5455/medarh.2014.68.394-398

28. Solbraa AK, Holme IM, Graff-Iversen S, Resaland GK, Aadland E, Anderssen SA. Physical activity and cardiovascular risk factors in a 40- to 42-year-old rural Norwegian population from 1975-2010: Repeated cross-sectional surveys. BMC Public Health. 2014;14:569. doi:10.1186/1471-2458-14-569

29. Sangaleti C, Trincaus M, Baratieri T, et al. Prevalence of cardiovascular risk factors among truck drivers in the South of Brazil. BMC Public Health. 2014;14:1063. doi:10.1186/1471-2458-14-1063

30. Tárraga López PJ, Garcia-Norro Herreros FJ, Tárraga Marcos L, et al. Intervención activa en la hipercolesterolemia de pacientes con riesgo cardiovascular alto de Atención Primaria; estudio ESPROCOL. Nutr Hosp. 2015;31:2261-2268. doi:10.3305/nh.2015.31.5.8795

31. Sugiyama D, Okamura T, Watanabe $M$, et al. Risk of hypercholesterolemia for cardiovascular disease and the population attributable fraction in a 24-year Japanese cohort study. J Atheroscler Thromb. 2015;22:95-107. doi:10.5551/jat.25908

32. AL-Nooh AA, Abdulabbas Abdulla Alajmi A, Wood D. The Prevalence of cardiovascular disease risk factors among employees in the Kingdom of Bahrain between October 2010 and March 2011: A cross-sectional study from a Workplace Health Campaign. Cardiol Res Pract. 2014;2014:1-9. doi:10.1155/2014/832421

33. Zaman F, Borang A. Prevalence of diabetes mellitus amongst rural hilly population of North Eastern India and its relationship with associated risk factors and related co-morbidities. J Nat Sci Biol Med. 2014;5:383. doi:10.4103/0976-9668.136195

34. Teramoto M, Moonie S, Cross CL, Chino M, Alpert PT. Association of leisure-time physical activity to cardiovascular disease prevalence in relation to smoking among adult Nevadans. PloS One. 2015;10:e0128424. doi:10.1371/journal.pone.0128424

35. Sepehri A, Palazón-Bru A, Gil-Guillén VF, et al. Diabetes screening: A pending issue in hypertense/obese patients. Peer J. 2015;3:e914. doi:10.7717/peerj.914

36. Ghassibe-Sabbagh M, Deeb M, Salloum AK, et al. Multivariate epidemiologic analysis of type 2 diabetes mellitus risks in the Lebanese population. Diabetol Metab Syndr. 2014;6:89. doi:10.1186/1758-5996-6-89

37. Zatońska K, llow R, Regulska-llow B, et al. Prevalence of diabetes mellitus and IFG in the prospective cohort "PONS" study - Baseline assessment. Ann Agric Environ Med. 2011;18:265-269. 
38. Rutkowski M, Bandosz P, Czupryniak L, et al. Prevalence of diabetes and impaired fasting glucose in Poland-the NATPOL 2011 Study. Diabet Med J Br Diabet Assoc. 2014;31:1568-1571. doi:10.1111/dme.12542

39. Wang K-S, Wang L, Zheng S, Wu L-Y. Associations of smoking status and serious psychological distress with chronic obstructive pulmonary disease. Int J High Risk Behav Addict. 2013;2:59-65. doi:10.5812/ ijhrba.10333

40. Park $H$, Jung SY, Lee $K$, et al. Prevalence of chronic obstructive lung disease in Korea using data from the Fifth Korea National Health and Nutrition Examination Survey. Korean J Fam Med. 2015;36:128-134. doi:10.4082/kjfm.2015.36.3.128

41. Clair C, Meigs JB, Rigotti NA. Smoking behavior among US adults with diabetes or impaired fasting glucose. Am J Med. 2013;126:541. e15-8. doi:10.1016/j.amjmed.2012.11.029

42. Polakowska M, Kwaśniewska M, Szcześniewska D, et al. Nałóg palenia tytoniu w populacji polskiej. Wyniki programu WOBASZ. Kardiol Pol. 2005;63:S1-5.

43. Völzke H, Ittermann T, Schmidt CO, et al. Prevalence trends in lifestylerelated risk factors. Dtsch Ärztebl Int. 2015;112:185-192. doi:10.3238/ arztebl.2015.0185

44. Karam C, Beauchet A, Czernichow S, et al. Trends in cardiovascular disease risk factor prevalence and estimated 10-year cardiovascular risk scores in a large untreated French urban population: The CARVAR 92 study. PloS One. 2015;10:e0124817. doi:10.1371/journal.pone. 0124817

45. Perez-Rios M, Fernandez E, Schiaffino A, Nebot M, Lopez MJ. Changes in the prevalence of tobacco consumption and the profile of Spanish smokers after a comprehensive smoke-free policy. PLOS One. 2015;10:e0128305. doi:10.1371/journal.pone.0128305

46. Go AS, Mozaffarian D, Roger VL, et al. Heart disease and stroke statistics - 2014 update: A report from the American Heart Association. Circulation. 2014;129:e28-292. doi:10.1161/01.cir.0000441139.02102.80

47. Romundstad $P$, Janszky I, Vatten L, et al. Cancer risk factors in Poland: The PONS Study. Ann Agric Environ Med. 2011;18:251-254.

48. Korhonen P, Vesalainen R, Aarnio P, Kautiainen H, Järvenpää S, Kantola I. Assessment of cardiovascular risk in primary health care. Scand J Prim Health Care. 2012;30:101-106. doi:10.3109/02813432.2012.675564

49. Dorobantu M, Bădilă E, Ghiorghe S, Darabont RO, Olteanu M, Flondor P. Total cardiovascular risk estimation in Romania. Data from the SEPHAR study. Rom J Intern Med. 2008;46:29-37.

50. Vikhireva O, Pajak A, Broda G, et al. SCORE performance in Central and Eastern Europe and former Soviet Union: MONICA and HAPIEE results. Eur Heart J. 2014;35:571-577. doi:10.1093/eurheartj/eht189

51. Shang X, Li J, Tao Q, et al. Educational level, obesity and incidence of diabetes among Chinese adult men and women aged 18-59 years old: An 11-Year follow-up study. PLoS One. 2013;8:e66479. doi:10.1371/ journal.pone.0066479

52. Strazzullo P, D’Elia L, Cairella G, Garbagnati F, Cappuccio FP, Scalfi L. Excess body weight and incidence of stroke: Meta-analysis of prospective studies with 2 million participants. Stroke. 2010;41:e418-26. doi:10.1161/STROKEAHA.109.576967

53. Hanson C, Rutten E, Wouters EFM, Rennard S. Influence of diet and obesity on COPD development and outcomes. Int J Chron Obstruct Pulmon Dis. 2014;9:723-733. doi:10.2147/COPD.S50111

54. Luppino FS, de Wit LM, Bouvy PF, et al. Overweight, obesity, and depression: A systematic review and meta-analysis of longitudinal studies. Arch Gen Psychiatry. 2010;67:220-229. doi:10.1001/archgenpsychiatry. 2010.2

55. Ogunmola OJ, Olaifa AO, Oladapo OO, Babatunde OA. Prevalence of cardiovascular risk factors among adults without obvious cardiovascular disease in a rural community in Ekiti State, Southwest Nigeria. BMC Cardiovasc Disord. 2013;13:89. doi:10.1186/1471-2261-13-89

56. Lee JW, Lim NK, Baek TH, Park SH, Park HY. Anthropometric indices as predictors of hypertension among men and women aged 40-69 years in the Korean population: The Korean Genome and Epidemiology Study. BMC Public Health. 2015;15:140. doi:10.1186/s12889-015-1471-5

57. An Y, Yi S, Fitzpatrick $A$, et al. Appropriate body mass index and waist circumference cutoff for overweight and central obesity among adults in Cambodia. PloS One. 2013;8:e77897. doi:10.1371/journal. pone.0077897

58. Asiki G, Murphy GAV, Baisley K, et al. Prevalence of dyslipidaemia and associated risk factors in a rural population in South-Western Uganda: A community based survey. PLOS One. 2015;10:e0126166. doi:10.1371/journal.pone.0126166
59. Cerhan JR, Moore SC, Jacobs EJ, et al. A pooled analysis of waist circumference and mortality in 650,000 adults. Mayo Clin Proc. 2014;89:335-345. doi:10.1016/j.mayocp.2013.11.011

60. Guh DP, Zhang W, Bansback N, Amarsi Z, Birmingham CL, Anis AH. The incidence of co-morbidities related to obesity and overweight: A systematic review and meta-analysis. BMC Public Health. 2009;9:88. doi:10.1186/1471-2458-9-88

61. National Cholesterol Education Program (NCEP) Expert Panel on Detection, Evaluation, and Treatment of High Blood Cholesterol in Adults (Adult Treatment Panel III). Third Report of the National Cholesterol Education Program (NCEP) Expert Panel on Detection, Evaluation, and Treatment of High Blood Cholesterol in Adults (Adult Treatment Panel III) final report. Circulation. 2002;106:3143-3421.

62. Esposito K, Kastorini C-M, Panagiotakos DB, Giugliano D. Prevention of type 2 diabetes by dietary patterns: A systematic review of prospective studies and meta-analysis. Metab Syndr Relat Disord. 2010;8:471-476. doi:10.1089/met.2010.0009

63. Sygnowska E, Waśkiewicz A, Głuszek J, et al. Spożycie produktów spożywczych przez dorosłą populację Polski. Wyniki programu WOBASZ. Kardiol Pol. 2005:63:S1-7.

64. Leon DA, Shkolnikov VM, Borinskaya S, et al. Hazardous alcohol consumption is associated with increased levels of B-type natriuretic peptide: Evidence from two population-based studies. Eur J Epidemiol. 2013;28:393-404. doi:10.1007/s10654-013-9808-9

65. Waśkiewicz A, Sygnowska E. Alcohol intake and cardiovascular risk factor profile in men participating in the WOBASZ study. Kardiol Pol. 2013;71:359-365.

66. Kim JY, Lee DY, Lee YJ, et al. Chronic alcohol consumption potentiates the development of diabetes through pancreatic $\beta$-cell dysfunction. World J Biol Chem. 2015;6:1-15. doi:10.4331/wjbc.v6.i1.1

67. Kiejna A, Piotrowski P, Adamowski T, et al. The prevalence of common mental disorders in the population of adult Poles by sex and age structure - An EZOP Poland study. Psychiatr Pol. 2015;49:15-27. doi:10.12740/PP/30811

68. Poulsen K, Cleal B, Clausen T, Andersen LL. Work, diabetes and obesity: A seven year follow-up study among Danish health care workers. PLoS One. 2014;9:e103425. doi:10.1371/journal.pone.0103425

69. Daniele TM da C, Bruin VMS de, Oliveira DSN de, Pompeu CMR, Forti ACE. Associations among physical activity, comorbidities, depressive symptoms and health-related quality of life in type 2 diabetes. Arq Bras Endocrinol Metabol. 2013;57:44-50.

70. Drygas W, Sakłak W, Kwaśniewska M, et al. Epidemiology of physical activity in adult Polish population in the second decade of the $21^{\text {st }}$ century. Results of the NATPOL 2011 study. Int J Occup Med Environ Health. 2013;26:846-855. doi:10.2478/s13382-013-0160-9

71. BiernatE, TomaszewskiP.Association of socio-economic and demographic factors with physical activity of males and females aged 20-69years. Ann Agric Environ Med. 2015;22:118-123. doi:10.5604/12321966.1141380

72. Garfield LD, Scherrer JF, Hauptman PJ, et al. Association of anxiety disorders and depression with incident heart failure. Psychosom Med. 2014;76:128-136. doi:10.1097/PSY.0000000000000027

73. Piwoński J, Piwońska A, Sygnowska E. Is there an association between depressive symptoms and coronary artery disease in the Polish adult population? Kardiol Pol. 2014;72:50-55. doi:10.5603/KP.a2013.0149

74. Choi NG, Kim J, Marti CN, Chen GJ. Late-life depression and cardiovascular disease burden: Examination of reciprocal relationship. Am J Geriatr Psychiatry. 2014;22:1522-1529. doi:10.1016/j.jagp.2014.04.004

75. van Marwijk HWJ, van der Kooy KG, Stehouwer CDA, Beekman ATF, van Hout HPJ. Depression increases the onset of cardiovascular disease over and above other determinants in older primary care patients, a cohort study. BMC Cardiovasc Disord. 2015;15:40. doi:10.1186/s12872-015-0036-y

76. Cooper DC, Trivedi RB, Nelson KM, et al. Sex differences in associations of depressive symptoms with cardiovascular risk factors and metabolic syndrome among African Americans. Cardiovasc Psychiatry Neurol. 2013;2013:979185. doi:10.1155/2013/979185

77. Gillen G. Coping during inpatient stroke rehabilitation: An exploratory study. Am J Occup Ther. 2006;60:136-145.

78. Klein DM, Turvey CL, Pies CJ. Relationship of coping styles with quality of life and depressive symptoms in older heart failure patients. J Aging Health. 2007;19:22-38. doi:10.1177/0898264306296398 